Port-Said University

Facultyof Commerce

Accounting and Auditing Department

\title{
Evaluating Online Auditing for Electronically Disseminated Financial Information to Minimize the Risks of External Auditor
}

\author{
Prepared by: \\ Omnia Farouk Abd El-Samia Mohamed El-Sokhary \\ Demonstratorin Accounting and Auditing Department \\ Faculty of Commerce \\ Port-Said University
}

Under the Supervision of:

Prof.Dr. Fouad Mohamed El-LeithyDr. Ahmed Mohamed Wageeh

Professor of Financial Accounting

Facultyof Commerce

Port-Said University

Lecturer of Accounting and Auditing Port-Said University 


\section{Abstract}

The Objective of the Study: The main objective of this study is to evaluate the risks and challenges that may face external auditors while adopting the online auditing to determine the extent of auditors' risks and responsibilities in such environment.

The Methodology of the Study: inorder to achieve this objective, the researcher used an experimental study to test the study's hypotheses, theresearcher selected a sample of (75) specialists from different categories to explore their opinion about the research's subject including: External Auditors, Financial Managers and Academics.

The Findings of the Study: The study's findings indicated that applying online auditing becomes imperative, there are some risks associated with online auditing practices and there is an ambiguity surrounding the auditors' role in respect to online auditing.

Key Words:Risks, Online Auditing, External Auditor. 


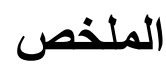

الهذف الرئيسي لهذه الدراسة هو تقييم المخاطر والتحديات التي من المدكن أن تو اجه المر اجع الخارجي أثناء تطبيق المر اجعة الفورية للبيانات المالية المنشورة إلكترونياً، وذللك بهدف تحديد مدي مسئوليات المر اجع في ظل هذه البيئة . و سعياً لتحقيق هذا الهذف قام الباحثباختيار عينة مكونة من (75) مفردة لإختبار أر ائهم حول فروض الدراسة ؛ وقد اشتملت العينة على : المر اجعيين الخارجيين، المديرين الماليين، والأكاديمين.وأهم ما توصلت إليه الدراسة هو أن تطبيق المر اجعة الفورية أصبح

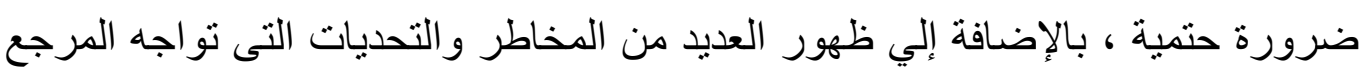

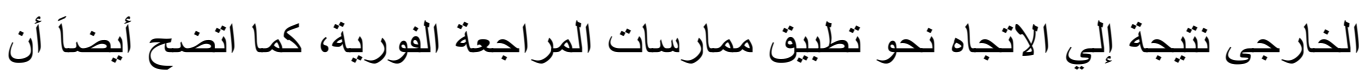
هناك بعض الغوض في دور ومسئوليات المراجع ومخاطر الخارجي فيما يتعلق بهذه البيئة عامة. الكلمات الدالة (المرشدة):المخاطر ، المر اجعة الفورية، المر اجع الخارجي. 


\section{Chapter One: The General Framework of the Research. 1.1 The General Framework of the Research}

\subsection{1: Introduction and Research Problem:}

Internet financial reporting (IFR) has become a quite trendy practice of communicating with stakeholders in recent times. However, unaudited financial information voluntary disseminated on the corporation's website may adversely affect the credibility of information and the user's confidently in this information. Therefore, there is a need for providing continuous assurance about this information and online audit report becomes imperative.As a result from the trend towards IFR and the online auditing process, many of the risks and challenges have been emerged which require a reconsideration of the professional requirements of external auditor in such environment.Therefore, in the researcher's view the effectiveness of online auditing depends on how external auditors deal with those risks and challenges. Thus, this study intended to evaluate the risks and challenges that may face external auditors while applying online auditing practices. In order to clarify the nature of those risks and challenges and minimize these risks to improve their professional performance.

\subsection{2: Research Objective and Importance:}

The importance of this research stems from the paucity of scientific research and specialized studies in The Egyptian business environment, whichevaluatingthe online auditing practicing, identifying the risks and challenges that may face external auditors in such environment in order to improve the professional performance of external auditors.

\subsection{3: Research hypotheses:}

The First Hypothesis (H1): There is no significant relationship between the widespread use of internet financial reporting and the need for applying online auditing.

The Second Hypothesis (H2): There is no significant relationship between implementing online auditing approach and arising some risks and challenges in front of professionals.

The Third Hypothesis (H3): There is no significant relationship between applying online auditing and the development in external auditor's roles and responsibilities.

\subsection{4: Research Methodology:}

To achieve the research objectives both inductive and deductive approaches are utilized. 


\subsection{5: ResearchStructure:}

Chapter One: The General Framework of the Research.

Chapter Two: Risks of External Auditors in Online Auditing Environment.

Chapter Three: The Extent of External Auditor's Responsibility within Online Auditing Environment.

Chapter Four: The Empirical Study.

Conclusion, References.

\section{2: Literature Review}

\subsection{1: Introduction:}

In this section, the researcher will review some of the literatures which are related to the research.

\subsection{2: Amin and Mohamed, (2016)}

This study examined how a continuous auditing system (CAS) can be implemented within an IFR environment. It also explored the perceptions of auditors in the Egyptian environment towards the role ofthe CAS to offset the challenges which threatening the quality of IFR. An empirical study was conducted to examine the study's hypotheses. The results indicated that, auditors in Egypt believed that the adopting of CAS could face the challenges and risks associated with IFR environment.Also, auditorsagreed that CAS is able to improve the quality of information in such environment.

\subsection{1: Eni, (2016)}

This study described a new technique of applying auditing by using online collaborative software which is an inter-organizational system that gathers a large number of financial auditors within a single network.

The results indicated thatin an online collaborative audit system, the exchange of information between the auditor, the client, and the oversight bodies could be easily enabled. Also, the online collaborative system based on Internet infrastructure which covers various stakeholders' needs such as;online data gathering and inspections, collect information about previous audits for the same audited entity. 


\section{Chapter Two: Internet Financial Reporting and Online Auditing, A Conceptual Framework}

\section{Introduction:}

IFR becomes widely adopted by most companies for providing useful and timely information for different users. As a result the online audit report must be provided as it adds value to the disseminated information, reduces the information risks, and finally maintain the decision-making process for all users.

\section{1: The General Framework of Internet Financial Reporting}

\subsection{1: The Nature of IFR:}

IFR represents one of the voluntary disclosure types provided on the public companies' websites through the Internet. Voluntary disclosure refers to the practices that companies adopted without any obligation regarding on it.IFR provides many benefits for both companies and users. For companies;it improves cost efficiency, promotes company to the public, and attracts more investors.For users;it allows flexible nonsequential access to the information through the hyperlinks, provides more information than available in the annual paper report,and increases the opportunity of providing real-time information for all users. Also, information provided in an interactive manner with the ability to search the content of the report.

\subsection{2: Internet Financial Reporting and Online Auditing}

As IFR is mainly voluntary and unregulated as there is no set of regulations organize the Internet Financial Reporting Practices and companies are under no obligation to maintain the credibility and confidently of the disseminate financial information through their websites.Therefore,there are some risks and challengesemerged as a result of adopting IFR practices, thismakes theimplementing of continuous online auditing (COA) practices more suitable auditing technique to offset such challenges and risks. Also,it can improve the quality and increase the credibility of the disseminated information. 


\section{2: Nature of Online Auditing}

\subsection{1: What Is Online Auditing?}

Online auditing is anewtechniquethat allowsauditorto access to business data of auditees and provide a continuous assurance simultaneously with or a short period of time after the occurrence of events underlying the subject matter, using an environment based on computer networks.

The benefits of applying COA can be classified into two kinds of benefits: benefits that can be measured in terms of money when implementing COA system, such as reducing staff costs, risk control costs and audit implementation costs. Benefits that cannot be measured in terms of money when implementing COA system. For instance, implementing COA system can reduce many types of audit waste as mentioned before, improve the efficiency and effectiveness of auditing process by providing more reliable, relevant and timely information and mitigates audit risk. Furthermore, implementing an online auditing system in continuous manner provides more valuable and secure information for all users

\subsection{2: Online Auditing Report and the Quality of Information}

Providing online audit report and adopting COA practices can enhance the quality of the disseminated information. This can be examined through the following characteristics of information:

Relevance:COA can be useful in providing more timely and reliable information for all users to avoid the risks associated with electronic transaction

Reliability: In order toavoid the manipulation of the disclosed information by internal or external usersand ensure thereliability ofdisseminated information, auditors shouldcontinuously monitoring the effectivenessof the AIS adopted by the management. So,adopting COA process can be useful in providing more reliable information to avoid the risks associated with electronic transaction

Comparability:Hyperlinks are commonly used to disseminate financial information in the companies' websites which increases the flexibility in the amount of information that can be acquired and the manner of information acquisition. Also, using, eXtensible Business 
Reporting Language(XBRL), as standardizing language for IFR can be effectively done with the help of COA as it enhances the quality of the IFR

\section{Chapter Three: A Prospective Professional Role of External Auditor toward Online Auditing Risks}

\section{Introduction:}

Although, COA can improve the quality of the disseminated financial information, some of the new challenges and risks have been raised.For instance, risks related to the responsibility of external auditor about the disseminated information and risks related to applying COA approach.The effectiveness of applying COA approach depends on how external auditors deal with these risks and challenges.

\section{1: Risks and Challenges of Online Auditing:}

\subsection{1: Risks Related to Applying COA Approach:}

The overall objective and scope of an audit does not change in a computer information systems (CIS) environment. However, auditors face different challenges and barriers when applying auditing to those systems. Although the COA process can reduce many risks of manual systems and in some cases eliminated it. However, there are risks specific toAccounting Information Systems(AIS) that can lead to significant losses if ignored. A major of those risks included: Risks Associated with the Lack of Auditor's Knowledge, Risks Associated with the Development in (AIS), Loss of Physical Evidences, and Risks Associated with Internal Control System.

\subsection{3: Risk Related to Online Audit Report:}

Despite the benefits that result from using the internet as a mean of financial reporting, many other challenges and risks are raised. Some of those risks are expected to affect the quality of the information generated within IFR environment, other affecting the auditor's role and responsibility towards such information.

The unregulated nature of the IFR raises issues and risks that expected to affect the quality of the information generated within such environment.Some of these issues include: Hyper-linking audited and unaudited financial information, unauthorized access and/ or modifications to IFR, omission of audit report, and Errors during the downloading and extraction processes. Such challenges, indeed, will affect the credibility of the disseminated information, and the external auditor's roles and responsibilities in this environment. 


\section{2: The Effective Role of External Auditor in Online Auditing Environment}

\section{Introduction:}

There is an ambiguity and confusion surrounding the role, responsibilities, and performance of external auditors with respect to IFR and online auditing. This mean that auditors need more guidelines, diverse methods and advanced audit tools techniques to cover the gap associated with auditor's responsibilities and performance with regard to this environment.

\section{2:1:The Auditor's Role and Responsibilities Regarding to Online Auditing Environment}

Changing the way of the disclosure by using internet will not change the auditor's responsibility towards auditing the financial statements of the auditee. Auditor still is responsible for checking the consistency between the actual financial statements and that published on the company's website. The followings aresome of the external auditor's roles and responsibilities with regard to such environment:

- Examining the control system over the electronic presentation of audited financial information on the entity's website.

- Ensuring that there are consistencies between audited information and disseminated information presented on the entity's website.

- Continually monitoring the entity's website to ensure that no inappropriate modifications are made to the audited financial statements after they have been published on the entity's website.

\section{2:2: Consequences of Using the Internet on Auditing Standards}

Current auditing standards should be revised to blend into a continuous online auditing process and enable more effective planning, risk assessment, and evidence gathering. ISA (500), ISA (530), ISA (570), and ISA (620) are among International Auditing Standards that need to address a different set of requirements. 


\section{Chapter Four: An Empirical Study}

\section{1: Introduction and the Objectives of the Study:}

In this chapter an empirical study wasconducted to investigate the specialists' opinion in the Egyptian environment about all aspects which the researcher stated during the theoretical part by using a questionnaire to test the hypotheses of the study.The researcher selected a sample of (75) specialists to explore their opinion including: External Auditors, Financial Managers, and Academics.

\section{2: Hypotheses Testing and Discussion of the Findings:}

The results of the empirical study provided the followings:

1- There is a Relationship between the Widespread Use of Internet Financial Reporting and Implementing Online Auditing Practices.

2- There is a Relationship between Implementing the Online Auditing Approach and ArisingSome Risks and Challenges in Front of the Professionals.

3- There is a Relationship between Applying Online Auditing and The Development in External Auditor's Roles and Responsibilities.

\section{Conclusions}

1- Internet Financial Reporting becomes Imperative, as it has a positive double effect for both companies and users.

2- Auditing should restructure aroundonline auditing, asunaudited financial information voluntary disseminated on the corporation's website may adversely affect the credibility of information and the user's confidently in this information.

3- As a result of the new technological developments, new challenges have been evolved. This enforced audit professionals to implement auditing practices in a continuous manner.

4- Online audit report adds value to the disseminated information, as it reduces the information risks and maintain the decision-making process for all users.

5- There arestill some ambiguity and confusions surrounding: The role, Responsibilities', and Performance of external auditors with respect to IFR and online auditing.

6- The researcher suggested that the professional bodies of Accounting in Egypt and those related to the American Accounting Association should generate new standards for the Accounting and Auditing aspects of the IFR, in order to reduce the risks and challenges 
surrounding their application. Meanwhile, this will provide more confidence to the stakeholders while using the IFR.

\section{References:}

1. Agboola, A. A. and Salawu, M. K., (2012),"The Determinants of Internet Financial Reporting: Empirical Evidence from Nigeria", Research Journal of Finance and Accounting, Vol. 3, No. 11, PP. 106-96.

2. Ahmed, A. H., Tahat, Y. A., Burton B. M. and Dunne, T. M., (2015), "The Value Relevance of Corporate Internet Reporting", Advances in Accounting, incorporating Advances in International Accounting, Vol. 31, PP. 188-196.

3. Ali Khan, M. N. A. A., Ismail, N. A. and Zakuan, N., (2013), "Benefits of Internet Financial Reporting in A developing Countries: Evidence from Malaysia", African Journal of Business Management, Vol. 7, No. 9, PP. 719-726.

4. Amin, H. M. G. and Mohamed, E. K. A., (2016), "Auditors' Perceptions of The Impact of Continuous Auditing on The Quality of Internet Reported Financial Information in Egypt", Managerial Auditing Journal, Vol. 31, No.1, PP. 1- 41.

5. Amin, H. M. G., and Mohamed, E. K. A., (2012), "Internet Financial Reporting, Quality of Information and Auditor's Responsibility in Egypt", Int. J. Economics and Accounting, Vol. 3, No. 3/4, PP. 276-294.

6. Chen, W., and Sifeng, L., (2012), "Influence Factors Analysis of Online Auditing Performance Assessment A Combined Use Between AHP and GIA", Auditing performance assessment, Vol. 41, No.5/6, PP. 587-598.

7. Eni, L. C., (2016),"Considerations Regarding the Design of An Online Collaborative Audit System",Managerial Auditing Journal, Vol. 31, No. 1, PP. 1-26.

8. Fisher. R. T. and Naylor, S. T., (2016), "Corporate Reporting on the Internet and the Expectations Gap: New Face of an Old Problem", Accounting and Business Research,Vol. 46, No. 2, PP. 196-220.

9. Ismail, T. H., and Sobhy, N. M., (2009), "Determinants of Auditors' Perceptions of The Work Needed in The Audit of Internet-Based financial Reports in Egypt", Journal of Applied Accounting Research, Vol. 10, No. 2, PP. 132-150. 